\title{
PHYLOGENETIC RELATIONSHIPS AMONG WEST INDIAN XENODONTINE SNAKES (SERPENTES; COLUBRIDAE) WITH COMMENTS ON THE PHYLOGENY OF SOME MAINLAND XENODONTINES
}

Brian I. Crother (bcrother@selu.edu)

Crother/White Molecular Phylogenetics Laboratory, Department of Biological Sciences, Southeastern Louisiana University, Hammond, Louisiana 70402

Abstract - The evolutionary relationships of the West Indian (W. I.) xenodontine snake assemblage has been considered as either monophyletic or paraphyletic. Allozyme data from protein electrophoresis were used to estimate the phylogeny of the W. I. xenodontine snakes. Forty-two species from 25 genera (mainland and W. I. taxa) were examined. The phylogenetic relationships were estimated using parsimony analyses with successive approximation weighting on the data coded two ways: (1) the allele as the character and (2) the locus as the character. The most parsimonious trees from both coding methods indicated a non-monophyletic W. I. xenodontine assemblage. Three W.I. groups were recovered in both coding methods: (1) Jamaican Arrhyton and Darlingtonia, (2) Uromacer and the Cuban Arrhyton, and (3) Alsophis, laltris, and the South American Alsophis elegans. The relationships of Hypsirhynchus, Antillophis and Arrhyton exiguum were unstable. Nomenclatural changes are recommended for Darlingtonia, Arrhyton, laltris and Alsophis.

\section{INTRODUCTION}

Dunn (1932) provided a general hypothesis of the relationships of the West Indian xenodontines based mainly on numbers of scale pits. He concluded that only three endemic genera were represented and contained the indicated 
nominal species: Arrhyton (redimitum, taeniatum, vittatum) on Cuba, and laltris (dorsalis) and Uromacer (oxyrhynchus, frenatus, catesbyi, wetmorei, scandax, dorsalis) on Hispaniola. He allocated the remaining xenodontines to either Alsophis (anomalus, leucomelas, sanctaecrucis, melanichnus, ater, rijer smai, variegatus, anegadae, antillensis, rufiventris, vudii, angulifer) or Dromicus (andreae, parvifrons, alleni, callilaemus, funereus, exiguus, stahli, ferox, juliae, cursor, ornatus, perfuscus, melanotus). These genera were divided into two groups: Arrhyton, Uromacer, and Dromicus with one scale pit (even though the Uromacer and Arrhyton recognized by Dunn have no scale pits) and Alsophis and laltris with two scale pits. Dunn (1932) thought that Arrhyton and Uromacer were derived from Dromicus, and laltris was derived from Alsophis.

Maglio (1970) presented the only other study that specifically addressed the phylogeny of the West Indian xenodontines. Maglio examined skull, hemipenes, and external characters and agreed with Dunn (1932) on at least one point: the West Indian xenodontine assemblage was not monophyletic. Otherwise, he disputed Dunn's conclusions, and indicated that Dunn's reliance on scale pit character states obscured the number of distinct taxa in the West Indies.

Maglio concluded that four separate groups made up the assemblage: (1) the cantherigerus group (Alsophis, Uromacer, Hypsirhynchus) that presumably originated in South America and is related to Philodryas, the South American and Galapagos Alsophis, and the Central American Conophis; (2) the melanotus group (Dromicus = Liophis), found only on the Lesser Antilles and with affinities to South American members of the same genus; (3) the andreae group (Antillophis), with affinities to Lygophis (=Saphenophis) boursieri of Ecuador and Colombia; and (4) the funereum group (Arrhyton and Darlingtonia), thought to be related to Rhadinaea, and perhaps of Central American origin. This was called the "funereus" group by Maglio, and is not in gender agreement with Arrhyton (neuter; Schwartz and Garrido, 1981). As such, the endings of the Arrhyton species names funereus, callilaemus, and exiguus shall be referred to herein as funereum, callilaemum, and exiguum. Maglio (1970) concluded that the relationships of laltris were enigmatic, but suggested it might have been derived from an Alsophis ancestor on Hispaniola. Maglio's systematic conclusions led him to re-assign a number of species referred to Dromicus by Dunn to other genera as follows: andreae and parvifrons to Antillophis; callilaemum, exiguum, funereu 
$m$, and polylepis to Arrhyton. Besides re-assigning species and naming the assemblages, Maglio presented phylogenies for each stock (Figure 1a-b), which provided testable hypotheses that may be compared with subsequent analyses.

The relationships proposed by Maglio (1970) have been controversial. Myers (1973), in a study of the genus Saphenophis, rejected any relationship between Antillophis and Saphenophis and suggested that the two Antillophis species may not even be congeners. Schwartz and Garrido (1981) did not regard the funereum assemblage as natural, but rather as based on convergent similarities. They concluded that the genus Arrhyton sensu Maglio was not a cohesive group.

Jenner (1981), in a review of xenodontine colubrid snakes (based on hemipenes, osteology, and distribution), indicated that the West Indian assemblage was monophyletic but also included two North American (Farancia and Heterodon) and three South American genera (Helicops, Uromacerina, and Hydrodynastes) in the tribe Alsophiini. This group was much reduced from Dowling and Duellman's (1978) Alsophiini of 44 genera. Jenner placed 11 genera in the tribe, which she characterized by the presence of a bilobed, semicapitate hemipenis with proximal spines, distal calyces, and a forked sulcus. When Jenner (1983) presented her classification of xenodontine snakes, she moved the northern tribes, the Alsophiini, Dipsadini, and Leptodeirini into their own subfamily, the Dipsadinae. This removed the West Indian assemblage from the Xenodontinae, rejected a Philodryas relationship as suggested by Maglio (1970), and suggested a Central American affinity for the West Indian assemblage. However, Jenner and Dowling (1985) later restricted the Dipsadinae to two tribes, the Dipsadini and Leptodeirini (based on their northern distribution, fully capitate hemipenis and immunological data) and returned the Alsophiini to the Xenodontinae.

Cadle (1984a,b,c) discussed relationships for many of the South American and Central American xenodontine genera based on immunological data. He included Alsophis (cantherigerus, vudii, rufiventris) and Hypsirhynchus from the West Indies. His data did not support an Alsophis-PhilodryasConophis relationship. In addition, his limited material neither allowed for rejection of relationships within Maglio's (1970) cantherigerus group, nor rejection of Maglio's hypothesis of a polyphyletic West Indian xenodontine assemblage because Cadle's taxa all belonged to the same cantherigerus group sensu Maglio. Based on these results, Cadle (1985) suggested that the West Indian assemblage was a compact monophyletic radiation (excluding the melanotus group), in sharp contrast to 
Maglio's overall view (1970). Cadle (1984c) also disagreed with Jenner's allocation of Heterodon and Farancia $(1981,1983)$ to the Alsophiini, because his data indicated that these genera were distinctive lineages (i.e. apparently not associated with any lineages examined by Cadle), not closely related to any South or Central American clade.

Recently, Crother and Hillis (1995) examined restriction sites of the nuclear ribosomal DNA repeat for a number of the West Indian taxa. The resultant phylogeny was largely at odds with the previous studies and only supported Maglio's (1970) proposed sister relationship between the Bahamian (vudii) and Cuban (cantherigerus) Alsophis. However, the Crother and Hillis (1995) study did not include many mainland taxa (only the North American Farancia) and had used a questionable outgroup.

The previous studies are not in agreement on the relationships and thus history of the West Indian xenodontine radiation. Cadle (1985) suggested that the West Indian xenodontines are a compact, monophyletic radiation, as did Jenner (1981); on the other hand, Dunn (1932) and Maglio (1970) proposed that the West Indian xenodontines are composed of multiple lineages with independent mainland affinities.

My study was motivated by the increased interest in geological and biological history of the Caribbean region along with an intrinsic interest in snake phylogeny and evolution. Because the studies reviewed above are not in agreement (possibly for any number of reasons, including the use of differing philosophies and methodologies [Kluge, 1991]), an additional data set, allozymes, was examined to address the phylogeny of the West Indian xenodontines.

\section{METHODS}

A total of 169 individuals representing 42 species from 25 genera were examined (see Table 1 for taxa and sample sizes). Seven of the nine Antillean genera were represented by 18 species and 109 individuals. The remainder of the samples are from North, Central, and South American taxa and represent seven tribes of the Xenodontinae and Dipsadinae as per Dowling et al. (1983) (see Material Examined for localities).

All personally collected material was either frozen whole in liquid nitrogen for later dissection or was dissected in the field. Samples of heart, liver, kidney 
and muscle tissue were removed, placed in cryogenic tubes and frozen in liquid nitrogen. These tissues were stored later at $-80^{\circ} \mathrm{C}$ for up to two years. Some samples were gifts and were already dissected and frozen; these were assumed to be of good quality unless suspected otherwise by the donor. Tissue homogenates were obtained by grinding the tissue in $0.25 \mathrm{ml}$ of $0.1 \mathrm{M}$ Tris- $\mathrm{HCl}$ buffer, $\mathrm{pH}$ 7.0.

Electrophoresis was carried out in the Biochemical Phylogenetics Laboratory at the University of Miami (FL) using standard horizontal starch gel electrophoresis (Murphy et al., 1990). Enzymes, tissue sources, electrophoretic conditions, and staining references are listed in Table 2.

Thirty-two presumptive gene loci were screened for interspecific variation. The electromorphs were qualitatively scored; the locus was considered the character and the allele(s) or allelic composition the character state (Buth, 1984a). Alleles were differentiated based on relative mobilities, which were assessed by side-by-side comparisons. For species that expressed more than one allele per locus (i.e. were polymorphic), the following coding rules were applied. If one allele was shared with other taxa and the remaining alleles were unique to the species (i.e. autapomorphies), the unique alleles were dropped from the analysis. If two alleles were present in a species, one of which was shared with the outgroup (i.e. a symplesiomorphy) and the other with some members of the ingroup (i.e. a synapomorphy), the symplesiomorphy was dropped from the analysis. Where such coding decisions could not be made, the presumptive homology was considered ambiguous and the locus was scored as a "?" for the taxon. Scoring polymorphisms in this manner (UP = uncertain polymorphisms, for the remainder) has at least two problems: (1) possible failure to find all the most parsimonious trees (Nixon and Davis, 1991), and (2) illogical transformations. An example of the latter would be if a taxon was polymorphic for $A$ and $B$, but after the analysis was inferred to evolve from neither A nor B, but from a different allele. Such transformations were evaluated on the resultant phylogeny.

In addition to the above coding procedure, each allele (or electromorph) was coded as a character, with presence and absence of the electromorphs as the states (P/A, independent allele model; Mickevich and Johnson, 1976). No frequency thresholds (e.g., > 0.05) were used in considering whether or not a allele was present, i.e., all alleles were scored. This coding method has the advantage of allowing the inclusion of all the data, but suffers from other shortcomings. Primarily, hypothetical ancestors that result from phylogenetic analysis may not have any alleles at a locus (Mickevich and Mitter, 1981), and 
this presumably is due to the possibility that alleles at a locus may not be independent. Mabee and Humphries (1993) suggested it was the result of poor character conceptualization and Murphy (1993) argued against it for additional reasons. Despite these problems, recent workers have found the method useful (Carpenter et al., 1993; de Queiroz and Lawson, 1994) and in fact Pleijel (1995) argued for the presence/absence coding approach and rejected concerns over all-absence internal nodes.

Heteropolymer assembly was also included as a character for the locus lactate dehydrogenase (LDH). The two loci of LDH interact to form discrete combinations of the four different subunits and these different subunit combinations have been suggested to contain phylogenetic information (Murphy and Crabtree, 1985). The utility of these data seems to be variable (contra, Murphy, 1988; pro, Sites et al., 1986; Werman, 1997); their usefulness was further evaluated in this study. Similar assemblies were scored the same, regardless of mobility differences. The characters were coded as follows: $B=$ five bands, $C=$ four bands $\left(A_{4}-B_{2} A_{2}-B_{3} A_{1}-B_{4}\right), D=$ three bands $\left(A_{4}-B_{2} A_{2}-B_{4}\right)$, and $E=$ two bands $\left(A_{4}-B_{4}\right)$. The inferred combinations were based on the symmetry of expression as compared to previous studies (e.g., Murphy and Crabtree, 1985; Sites et al., 1986).

\section{Outgroup}

As noted previously, no single, consistent hypothesis has been presented concerning specific sister group relationships for any West Indian taxa. Consequently, the only level of generality that can be accepted is that the genera are xenodontines (and dipsadines according to Dowling et al., 1983). Even this designation is dubious because no synapomorphies have been identified to unite the Xenodontinae (Cadle, 1984c, 1988; McDowell, 1987) as compared to other colubrid lineages. Thus, Nerodia fasciata of the colubrid subfamily Natricinae was included as the initial outgroup in this study to ensure that the ingroup was compared at a level where it was monophyletic relative to the outgroup (Watrous and Wheeler, 1981; Schwaner and Dessauer, 1982; Maddison et al., 1986).

\section{Data Analyses}

Phylogenetic analyses and character evaluation were conducted with the computer software PAUP version 3.1.1 (Swofford, 1993) and MacClade version 3.01 (Maddison and Maddison, 1992). The character states were analyzed as unordered (see the Discussion for comments). Mostparsimonious trees were found using the random addition sequence for 
stepwise addition 25 times and the heuristic branch swapping algorithm (TBR - tree bisection and reconnection) in which all possible bisections and pairwise reconnections are examined for character fit. MULPARS was employed to retain multiple most parsimonious trees (mpts) and the maximum number of mpts to be retained was set at 10,000 trees (MAXTREES option). Steepest descent was off and zero-length branches were collapsed. Accelerated transformation (ACCTRAN option) was used to optimize character state distributions. After the random addition iterations were completed and the presumed shortest tree island(s) found, multiple most-parsimonious trees were combined into strict consensus trees (Sokal and Rohlf, 1981) to identify repeatedly supported clades. To reduce the number of mpts, and possibly increase phylogenetic signal relative to noise (Campbell and Frost, 1993), a posteriori successive approximation weighting (SAW; Farris, 1969) was applied. This is a method of differential character weighting based on relative statistical scores (consistency index, rescaled consistency index, or retention index) for each character. As such, the weights are based on "cladistic reliability" (Campbell and Frost, 1993:65), or, as put by Carpenter et al. (1993:1338), "the characters judge themselves to indicate which ones are properly interpreted as synapomorphies". The method may be considered controversial due to circularity (e.g., Cannatella and de Queiroz, 1989; Swofford and Olsen, 1990), but it has been argued that circular was confused with recursive (Carpenter et al., 1993). Given that, the SAW analysis is worth utilizing in cases where large numbers of mpts may obscure phylogenetic signal. However, Carpenter et al. (1993) suggested that data that produced novel trees from a SAW analysis may be suspect for recovering evolutionary history. In this study, the retention index was used in the SAW analysis. The weighting was conducted only on the shortest trees found in the previous analyses.

The level of phylogenetic signal, and thus the utility of this relatively small data set to resolve historical patterns among the large number of taxa, was of concern. To check for the level of signal in the data (as inferred from the structure of the data), the g1 statistic (Hillis, 1991; Huelsenbeck, 1991) was measured for tree length frequency distributions. The g1 is one of a number of phylogenetic signal or support statistics that have been recently developed (e.g., bootstrap, Felsenstein, 1985; PTP, Faith and Cranston, 1991). These statistics have all been criticized (e.g., Carpenter, 1992; Hillis and Bull, 1993; Källersjö et al., 1992; Kluge and Wolf, 1993; Farris et al., 1994) and because they all deviate from an ultimate criterion such as minimum length, perhaps their importance should be downplayed (Carpenter, 1992; Kluge and Wolf, 1993). Nonetheless, but yet fully aware of the potential for the g1 to mislead 
(Källersjö et al., 1992), the tree length distribution measure was used herein. The $\mathrm{g} 1$ was obtained for the entire data sets (for matrices from each coding method) from samples of 50,000 random trees. For subset clades with less than 10 taxa the g1 was obtained from exhaustive samples, and for clades larger than nine taxa the g1 was obtained from samples of 5000 random trees. Each g1 was checked for significance based on Hillis and Huelsenbeck (1992).

\section{RESULTS}

Of the 32 screened loci, 19 were phylogenetically informative, i.e. they were neither invariant across all taxa nor unique for a single taxon. Differentiation among the 42 taxa was such that 142 alleles were present (Appendix 1). The number of alleles per locus ranged from four (Pep-D) to 23 (Ldh-B). Three different patterns of $\mathrm{LDH}$ heteropolymers were found among the taxa: three bands $\left(A_{4}-A_{2} B_{2}-B_{4}\right)$, four bands $\left(A_{4}-A_{2} B_{2}-A_{1} B_{3}-B_{4}\right)$, and five bands $\left(A_{4}-A_{3} B_{1}-A_{2} B_{2}-A_{1} B_{3}-B_{4}\right)$. In addition to these heteropolymers, $a$ single banded pattern (either $\mathrm{A}_{4}$ or $\mathrm{B}_{4}$ ) and a two banded pattern (presumably $\mathrm{A}_{4}-\mathrm{B}_{4}$ ) were found.

The $g 1$ for the entire UP data set (Appendix 2$)$ was $-0.338(P<0.01)$ and the g1 for the entire P/A data set (Appendix 3$)$ was $-0.346(P<0.01$; these $P$ values were inferred from Table 1 and Table 2 in Hillis and Huelsenbeck, 1992). The g1 critical value suggests that the data have significantly more structure than random data (Hillis and Huelsenbeck, 1992). The g1 values for subsets of the P/A data (which corresponded to all the major clades above the following branches: 5, 6, 12, 13, 18, 19, 26, 27, 33; refer to Figure 2) were all significant at $P<0.01$ except for the clades above branches 13 and 33 . These latter two were significant at $P<0.05$. The $g 1$ values for subsets of the UP data (the major clades above the following branches: 1, 3, 4, 5, 6, 7, 9, 10; refer to Figure 3 ) were significant at $P<0.01$. The data subsets defined by branches 2, 8, and 11 yielded non-significant $g 1$ values.

The random addition iterations of the UP-coded data recovered $9662 \mathrm{mpts}$ at 210 steps, each with a $\mathrm{Cl}=0.533$ and $\mathrm{RI}=0.622(\mathrm{Cl}=$ consistency index, Kluge and Farris, 1969; RI = retention index, Farris, 1989). The SAW analysis on the 210 step trees resulted in $668 \mathrm{mpts}$, increasing the $\mathrm{Cl}$ to 0.576 and the $\mathrm{RI}$ to 0.682 . Despite what appears to be a high number of mpts, this represents only a tiny fraction of the approximately $8^{1058}$ possible unrooted trees for this study (Felsenstein, 1978). The strict consensus tree (Figure 3) 
differed from the unweighted result only by increasing the resolution of relationships. Thus, the SAW analysis yielded a subset of trees from the unweighted analysis. No characters provided unambiguous support and only five characters (mACON, PGM, PEP-S, PGDH-2, and LDH heteropolymer assembly) had electromorphs (one each) that unambiguously supported clades. Out of the 40 polymorphisms coded as uncertain (?), 39 changed logically on the tree. The single illogical change was for Leptodeira at the mACON locus. Leptodeira was polymorphic for A and J, but reconstructed as having the B allele.

The strict consensus tree (Figure 3 ) was largely resolved and depicts a nonmonophyletic West Indian xenodontine assemblage distributed in four groups:

(1) Alsophis - laltris - Rhadinaea - Urotheca, (2)

Jamaican Arrhyton - Darlingtonia, (3) Uromacer - Cuban and Puerto Rican Arrhyton - Amastridium,

(4) Hypsirhynchus - Antillophis - Saphenophis - Xenodon - Oxyrhopus. Group 2 is the sister clade to a strictly mainland group composed of Imantodes - Geophis - Crisantophis - Conophis - Coniophanes - Enulius. Another mainland clade composed of Ninia - Sibon - Manolepis - Tretanorhinus was the sister group of the above groups. Farancia and Leptodeira were the most basal taxa, respectively.

The random addition iterations of the presence/absence $(\mathrm{P} / \mathrm{A})$ coded data recovered $958 \mathrm{mpts}$ at 414 steps $(\mathrm{Cl}=0.367, \mathrm{RI}=0.513)$. The SAW analysis on the 414 step trees resulted in a single $\mathrm{mpt}(\mathrm{Cl}=0.478, \mathrm{RI}=0.626$; Figure 2). Character support and distribution for the P/A result is detailed in Appendix 4 . As in the previous SAW analysis result, the tree was not novel, but one with increased resolution relative to the consensus of the original $958 \mathrm{mpts}$. Using the SAW analysis as the arbiter (Carpenter et al., 1993), the mpt from the P/A coded data was considered the best estimate of phylogeny. However, some hypothetical ancestors on the tree had loci which were not assigned any alleles. For example, SOD had no alleles on branches 6, 7, 8, 9, 11, 30 and AP had no alleles on branches 4 - 11 (refer to Figure 2 for branch labels). Only four characters provided unambiguous support for clades: character 35 branch 32, 59 - 17, 78 - 32, and 79 - 35. The tree was fully resolved and clustered the West Indian taxa into three related groups, each with mainland components. These groups are (1) Alsophis - laltris - Manolepis - Puerto Rican Arrhyton, (2) Jamaican Arrhyton - Darlingtonia - Antillophis - Hypsirhynchus - Farancia, and (3) Uromacer - Cuban Arrhyton - Saphenophis - Oxyrhopus - Conophis. Most closely related to these three groups was a clade composed 
of Rhadinaea - Urotheca - Amastridium - Geophis, and outside that group was another mainland clade composed of Imantodes - Sibon - Tretanorhinus - Ninia - Xenodon. The basal taxa, from closest to furthest from the above groups, were Crisantophis, Enulius, Coniophanes, and Leptodeira.

The LDH heteropolymer assembly character exhibited homoplasy for every character state in both the UP and P/A trees, except for state B which was the presence of five bands. This character state unambiguously supported the Arryhton funereum - A. polylepis sister relationship (this clade was also supported by five characters in the UP analysis and seven characters in the $\mathrm{P} / \mathrm{A}$ analysis). Overall, the LDH heteropolymer assembly character had a $\mathrm{Cl}=$ 0.36 on the $\mathrm{P} / \mathrm{A}$ tree and $\mathrm{a} \mathrm{Cl}=0.53$ on the UP tree.

\section{DISCUSSION}

\section{Evaluation of the Data}

The utility of allozyme data to reconstruct phylogenetic relationships has long been recognized, and this recognition has resulted in the extensive use of these data for phylogenetic studies (see Murphy et al., 1990, for a recent review). The remaining controversies that surround allozyme data concern methods of analysis, sample size, and the level of taxonomic appropriateness.

The debate over analyzing allozyme data as distances or as discrete characters has been lengthy (e.g., Farris 1981, 1985). Using allozyme data as discrete characters affords many biological and operational advantages over distance methods and has a key advantage in that the support for each node or terminal taxon is explicit (Murphy et al., 1990, and references within). But with the choice of discrete characters comes an additional analytical problem: the use of polymorphic characters, in this case allele frequencies. By nature, they often cannot be coded in a discrete character analysis, and as such are discarded or combined (e.g., Buth, 1984b; Miyamoto, 1983; Crother et al., 1992). Although the addition of missing data values into a matrix is not desirable, at the current time it is an option and not an illogical one as long as the character state changes into the coded missing data are defensible. Nixon and Davis (1991:233) commented on the use of missing values and identified potential problems; however, they explicitly point out that the problems and their method are for polymorphic characters "within a taxonomic grouping of species" and not for "attributes that are polymorphic within species." The 
polymorphisms of concern in this study are all of the latter type. Swofford and Berlocher (1987) demonstrated that the inclusion of allele frequency data reduces a sampling error inherent in presence/absence coding. However, Crother (1990) noted the possibility that frequency data may not be appropriate for estimating phylogeny because of their tendency to fluctuate temporally. Murphy (1993) expressed further concern over the use of allele frequencies. Among other problems, he noted that some frequency changes are based on non-heritable processes (e.g., drift or natural selection), and that such changes should not be given equal weight to frequency changes that result from heritable processes (mutation). Mabee and Humphries (1993) suggested that using a step matrix method, thus ordering the allozyme character states, would reduce the amount of assigned missing values and would increase the amount of information extractable from the data. The logic presented by Mabee and Humphries (1993; see also Murphy, 1993 for a similar concern for ordered allozyme data) for ordering the states assumes (although not stated explicitly) that the patterns of allozyme variability follow a stepwise mutation model (Ohta and Kimura, 1973). Unfortunately, this model has long been inferred to be incorrect through empirical study (Fuerst and Ferrell, 1980). Given the above discussion, the best method for coding allozyme information perhaps remains to be derived (or may come in the form of mutation coding as suggested by Murphy et al., 1996). As such, the inclusion of missing values in the coding of allozyme data remains a potentially undesirable but necessary aspect.

In this study, the UP coding method performed well, as far as yielding few illogical transformations. As noted above, out of 40 "?" coded polymorphisms, only a single illogical change occurred, and this change may in some way be associated with the basal position of the taxon. The reason this coding method performed well may simply be due to character congruence; the rest of the characters provided enough information to logically place the uncertain characters.

The allele P/A method performed better than the UP method in the sense that it yielded fewer mpts (one versus 668) and consequently greater phylogenetic resolution (Figure 2). Unfortunately, because hypothetical ancestors were assigned no alleles for various loci (failing Occam's Probative; Mickevich and Mitter, 1981), the reliability of the phylogeny may be suspect (but see Pleijel, 1995). However, all the arguably "known" intra-generic monophyletic groups, (Geophis, Downs, 1967; Imantodes, Myers, 1982; Ninia, Savage and Lahanas, 1991; Uromacer, Horn, 1969) were recovered only in the P/A analysis. Regardless, caution must be used in accepting this estimate of 
phylogeny as accurate. Carpenter et al. (1993) came to similar conclusions about the performance of the independent allele coding: reduction in ambiguity, increase in resolution, but no alleles for some loci at inferred ancestors.

Small sample size in this study is an area of potential concern for a reliable estimate of phylogeny. Small samples may inhibit the discovery of variation within and among taxa and as such may result in a misleading phylogeny. However, several phylogenetic studies employing allozymes and based on small sample sizes have shown congruence with other data sets (see citations in Hillis, 1987; Crother et al., 1992). Also, Hillis (1987) demonstrated through a posteriori selection of single individuals to represent species (in all possible combinations) that the reduced samples did not change inferred relationships found from larger samples. Although large sample sizes are preferable when many individuals (and especially many populations) can be collected, available data suggest that small sample sizes often are sufficient to confidently estimate phylogeny.

Coupled with small sample size is the small number of loci that were informative in the study and the intergeneric level of comparison. These points raise the concern that the characters may be too few and the taxa too diverse for estimating phylogeny with allozyme data. If such is the case, it would be expected that the data would not possess phylogenetic signal. Hillis (1991) and Huelsenbeck (1991) have shown that a strongly skewed distribution of tree lengths indicates that a data set contains phylogenetic signal. (But Källersjö et al. [1992] provided example data sets contrary to the claims of Hillis [1991] and Huelsenbeck [1991]. It seems that the method is sensitive to data sets structured in a way that yields high numbers of multiple most parsimonious trees.) If the distribution is symmetric or nearly so, it suggests that the data are randomly structured and the observed interspecific variation contains little historical information. Because of the number of taxa involved, obtaining the universe of tree lengths was prohibitive (with 42 taxa the total number of unrooted trees is $8^{1058}$; Felsenstein, 1978). Instead, random samples were taken (see methods) which resulted in strong left skews ( $P<$ $0.01)$ for both data sets. These results may indicate a high signal-to-noise ratio for the data, which may imply the presence of historical information.

The taxa included herein range from sister species to widely divergent taxa whose most recent ancestor has a minimum age of approximately 30 million years (Cadle, 1985, 1987). This is an extremely conservative estimate considering the earliest fossils assigned to the Colubrinae (Rage, 1987; Holman, 1984). If the West Indian taxa fit a vicariance model (e.g., Rosen, 
1975; Savage, 1982; Crother and Guyer, 1996), then the assemblage would have to be between about 50 and 80 million years old based on geologic evidence (Late Cretaceous-Early Tertiary; Pindell and Barrett, 1990). Thus, the natricine-xenodontine split may be older. Microcomplement fixation studies on albumin (Cadle, 1984a, b, 1988; Dowling et al., 1983) and transferrin (Schwaner and Dessauer, 1982) indicate that the distances between some xenodontine lineages are equal to or exceed the average distances that separate xenodontines and other major colubrid lineages (e.g., xenodontines and colubrines or natricines; Cadle, 1984c). Assuming equal rates of change, these data suggest that the lineage splits within the Xenodontinae may not be much younger than the xenodontine-natricine split. As such, if Hillis (1991) and Huelsenbeck (1991) are correct in their method to assess phylogenetic signal, then this study suggests that allozyme evolution among colubrid snakes has been conservative for many loci.

Monophyly of West Indian Xenodontines

The phylogenetic results of the two allozyme data sets suggest that the W. I. assemblage of xenodontines is not monophyletic relative to mainland New World xenodontines (Figure 2 and Figure 3 ). In broad terms, this result supports the conclusions of Dunn (1932) and Maglio (1970) and rejects the hypotheses of Jenner (1983) and Cadle (1985).

Dunn's (1932) broad separation of the W. I. xenodontines into two groups is partially supported by the allozyme data. One of his groups included Dromicus (= Antillophis, Hypsirhynchus, and Arrhyton [and Liophis, which was not included in this study] sensu Maglio, 1970), Uromacer, and Arrhyton. The other group included Alsophis and laltris. My results (from both coding approaches) also depict a split, with Alsophis - laltris as one group, and the other of Dunn's groups scattered among either two or three clades. In addition, each has internested mainland taxa. Dunn (1932) made no comment on the mainland relationships of these W. I. groups.

Nonetheless, it is intriguing that number of scale pits (upon which Dunn's separation was based) is congruent with the allozyme data for one group.

More specifically, these results suggest perhaps three or four groups within the W. I. xenodontine radiation, which is similar to the conclusions of Maglio (1970). Also like Maglio (1970), the W. I. xenodontine relationships appear to be with mainland taxa. However, the composition of these groups, although similar to Maglio's (Figure 1a-b), differ in several aspects. The groups found herein, that is the groups in common between the two results (without Liophis, which constituted one of Maglio's assemblages) are: 1) the 
Jamaican Arrhyton and the monotypic Darlingtonia, 2) Uromacer and the Cuban Arrhyton, 3) Alsophis, laltris and the mainland Alsophis elegans. These groups depart from Maglio's (1970) hypothesis in that Uromacer is not related to Alsophis, but apparently related to Cuban Arrhyton and that Maglio's funereum assemblage is polyphyletic. Three taxa could not be placed in this study, Hypsirhynchus, Antillophis, and Arrhyton exiguum. In either result Hypsirhynchus was not placed with Alsophis or Uromacer, as suggested by Maglio (1970). Antillophis switched from a sister relationship with Saphenophis (as suggested by Maglio but rejected by Myers, 1973) to the sister of Arrhyton-Darlingtonia. Arryhton exiguum bounced from the Uromacer clade to the Alsophis clade. Maglio (1970) recognized the peculiarity of exiguum and though he included it in the genus Arrhyton, he considered it the sister taxon of Darlingtonia. He also noted that exiguum might possibly not even be phylogenetically related to Arrhyton or Darlingtonia and this is not contradicted by the allozyme data.

These groupings support some of the previous disagreements with Maglio's (1970) conclusions. Schwartz and Garrido (1981) suggested that the published funereum group (sensu Maglio) was not monophyletic but based on convergent similarities. The allozyme data (both coding methods) support this contention, clearly splitting the funereum assemblage of Maglio into at least two groups, one with Darlingtonia and the Jamaican Arrhyton and the other with Cuban and Puerto Rican Arrhyton (see above). It seems clear that Arrhyton is not monophyletic and that the taxonomy warrants change. Hedges and Garrido (1992) stated the same, but their ideas of classification were based on Maglio's phylogeny. Based on the results herein, I recommend the following taxonomic changes: the contents of the clade that contain Arrhyton funereum, callilaemum, polylepis and Darlingtonia would be assigned the genus Darlingtonia (Table 3 ). Arrhyton is the older name, but because the Cuban taeniatum is the type species for Arrhyton, the clade would take the name of Darlingtonia.

An additional nomenclatural change that seems supported by the data is the inclusion of laltris in the genus Alsophis. Maglio (1970) did not place laltris in any of his groups, but he did suggest that if laltris were related to any West Indian taxon, it was Alsophis because it was similar in a number of skull characters. The Alsophis-laltris clade was supported by seven allozyme characters in the P/A analysis. As such, it may be instructive to synonymize laltris with Alsophis to reflect their phylogenetic relationship. Synonomizing laltris with Alsophis raises a homonym problem because the epithet dorsalis already is present in Alsophis. The next available name 
for Alsophis (= laltris) dorsalis is mentalis Günther, 1862. The new combination for laltris dorsalis is Alsophis mentalis (Table 3).

Myers (1973) was adamant about rejecting Maglio's (1970) contention that Antillophis and Saphenophis were related. The allozyme data support Myers' rejection in one case (P/A analysis), but Maglio's (1970) scenario is support by the UP hypothesis. Clearly, rejection or acceptance of one hypothesis over the other cannot be made at this time, but will require additional data to resolve the question.

\section{Broader Xenodontine Relationships}

Cadle (1984a-c, 1985, 1987, 1988) estimated xenodontine relationships using micro-complement fixation immunological distances (Champion et al., 1974; Maxson and Maxson, 1990). Cadle recovered patterns that can be evaluated relative to the allozyme results. Perhaps most significantly, Cadle's (1984a, b, 1988) data suggested a split within the Xenodontinae broadly along geographic lines: one lineage Central American and the other lineage South American (described further in Cadle and Greene, 1993). These results from the independent allele analysis also suggest such a split, and nearly as strongly as Cadle's results. The taxa in Cadle's Central American group which overlap with this study

(Amastridium, Coniophanes, Geophis, Imantodes, Leptodeira, Ninia, Sibon, Tr etanorhinus, Urotheca [ = Pliocercus]) compose the basal portion of the tree (and are not monophyletic), exclusive of the South American taxa (with the anomalous exception of Xenodon). These taxa also were considered Central American by Savage (1982). The overlapping South American taxa (Alsophis, Hypsirhynchus, Oxyrhopus) are spread through three well-defined clades composed mostly of W. I. taxa (which Cadle considers South American) and are exclusive of non-South American taxa, with the exception of Farancia. So the departure from a perfect South American - Central American split (if one follows the notion that the W. I. taxa are South American) comes from the placements of Farancia and Xenodon.

An interesting exception to this split is Rhadinaea, which Cadle (1984b) concluded was polyphyletic because it had affinities with both South and Central American taxa. The immunological data suggested that the Central American $R$ hadinaea were probably not monophyletic, with different species of Rhadinaea related to different Central American genera. As noted by Cadle (1984b), Myers (1974) recognized the possibility of Rhadinaea (sensu Myers) being non-monophyletic. The species included in this study were guentheri, godmani, and calligaster, all of which are from different 
species groups than those examined by Cadle. The species guentheri (and the entire lateristriga species group of Rhadinaea) was recently removed from Rhadinaea and combined with Pliocercus in the resurrected genus Urotheca (Savage and Crother, 1989). However, like Cadle's results, Rhadinaea (sensu Myers, 1974) proved peculiar in terms of phylogenetic relationships. Rhadinaea and Urotheca formed a well-supported clade (eight characters in the UP tree, seven in the P/A tree) which was alternatively internested within Alsophis or in a clade with Amastridium and Geophis. Interestingly, Myers (1974) suggested that at least one species group of Rhadinaea, the brevirostris group, had a history independent of other Rhadinaea and may have been derived from an alsophiine ancestor. Although no representatives of the brevirostris group were included in this allozyme study, the possible support of Myers' hypothesis for other Rhadinaea is intriguing. The allozyme data do not support the suggestion that Rhadinaea is either the sister to Coniophanes (Myers and Campbell, 1981) or closely related to Arrhyton as suggested by Maglio (1970). The relationships among Urotheca guentheri, Rhadinaea godmani and $R$. calligaster were unresolved (resolved in P/A result, unresolved in the UP result) but certainly support the previous inclusion of guentheri in Rhadinaea (Myers, 1974). Unfortunately, none of the ringed Urotheca (e.g., elapoides) were included to test the hypothesis of Savage and Crother's (1989) inclusion of the lateristriga group in the resurrected genus Urotheca.

The genera Amastridium and Tretanorhinus have been enigmatic in terms of their phylogenetic relationships. Cadle (1984b) could not place either specifically but unequivocally concluded that they were both part of the Central American group of xenodontines. The general consensus from morphology is that Amastridium is not closely related to any Middle American taxa (Dunn, 1925; Wilson and Meyer, 1969; Scott, 1969), even though it is part of the Middle American element (Savage, 1982). The P/A tree (Figure 2) supports Cadle's conclusion whereas the UP tree (Figure 3 ) suggests a novel hypothesis about the relationships of Amastridium. In the P/A analysis, Amastridium is in a clade with Geophis, Rhadinaea, and Urotheca and is the sister to the Rhadinaea-Urotheca group, which adds further support to the notion that Amastridium is Middle American. The UP results (Figure 3 ) suggest that the relationships of Amastridium lie in the Caribbean, possibly with the Cuban Arrhyton. This possibility has not been suggested before and indeed in general habitus they are similar. Supralabial, infralabial, and scale row counts are all the same, to the exclusion of the Jamaican and Puerto Rican Arrhyton. Maxillary tooth counts are also similar, 
but only in that they overlap. But detailed cranial osteological comparisons are needed to clarify the possible phylogenetic relationship between Amastridium and Cuban Arrhyton.

Other than being Middle American (Cadle, 1984b; Savage, 1982) with a Cuban representative, little is yet known about the affinities of Tretanorhinus. Pinou and Dowling (1994) established that Tretanorhinus was not a natricid, but a dipsadid. Dunn (1939) presented specific hypotheses of relationships and his ideas included Ninia, Amastridium, Hydromorphus, and what he called the Rhadinaea-Coniophanes-Trimetopon series. Allozyme data for Hydromorphus were not collected so comments cannot be made on that possibility, but the allozyme results do seem to exclude Amastridium and the Rhadinaea-Coniophanes-Trimetopon series. The allozymes do not exclude the possibility of a Ninia affinity, in that they are in the same clade, but the phylogenies depict Tretanorhinus as the sister to a Sibon-Manolepis clade or just to Sibon. The latter relationship is peculiar and requires additional data for elucidation.

Another historically enigmatic taxon that could not be resolved herein was Conophis. Wellman (1963) considered Conophis to have no close extant relatives. Cadle (1984c) concurred but did not rule out the possibility that Conophis may be related to a neotropical lineage. The P/A study suggested a sister relationship with Oxyrhopus and the UP study placed Conophis in a clade which containing Geophis, Imantodes, and Crisantophis. Like Wellman and Cadle, I cannot resolve the relationships of Conophis with the data at hand.

Cadle (1984c) concluded that the relationships of Farancia are enigmatic, but like other enigmatic xenodontines he did not rule out the possibility that Farancia was related to a neotropical lineage. The allozyme data were equally equivocal on the relationships of Farancia. The relationship consistently found shows Farancia as internested, not outside of the West Indian, Middle and South American taxa. In one case (Figure 2) Farancia falls out as the sister to a West Indian clade and in the other (Figure 3), Farancia is placed near the base of the tree. As such, the relationship of Farancia appears to indeed be Neotropical and this suggests that Farancia is a relict lineage, long disjunct from its Neotropical relatives.

The monotypic genus Manolepis is another phylogenetically enigmatic taxon included in the present study. Current thought (Jenner, 1981) considers Manolepis (distributed in the southwest of Mexico) to be a South American relict, occupying a disjunct distribution. Possible affinities are with 
the Philodryini (Jenner, 1981), but neither of the analyses herein support this contention. However, Manolepis was placed (in the P/A tree) as the sister to Alsophis, which Cadle (1984a) considered South American. On the other hand, the UP tree indicated a grouping with Sibon and Tretanorhinus. Considering the general morphology of Manolepis, the former hypothesis appears more reasonable. (Robert Thomas, pers. comm., considers Manolepis and Hysirhynchus to be closely related but the allozymes do not support the idea.)

The subfamily Xenodontinae had been divided most recently by Jenner (1983) into tribes and another subfamily, the Dipsadinae (both were elevated to family status in Dowling and Jenner, 1988), based largely on dentition, hemipenes, and distribution. Such divisions and groupings imply that taxa within those groups are natural, that is, they are monophyletic. Because at least two taxa (except for the Xenodontini) from most tribes of the two subfamilies were included in the present study, the implied monophyly of these tribal allocations could be examined. Interestingly, not one of the tribes formed a monophyletic group, nor did either of the subfamilies. Based on allozyme data then, in general the tribal allocations do not appear to be natural.

Jenner and Dowling (1985) also presented a phylogenetic hypothesis on the relationships of the xenodontine tribes. If the P/A tree is pruned so only the same taxa (as in Jenner and Dowling) are shown, the hypotheses are almost entirely consistent. Alsophis is sister to the Pseudoboini, Xenodon is sister to that clade, and Coniophanes and Leptodeira are outside those three taxa. The difference is in the Coniophanes-Leptodeira relationships. Jenner and Dowling (1985) depict them as sister taxa whereas the phylogeny herein (when pruned) would show Leptodeira outside of Coniophanes, which would be the sister to the former three taxa.

\section{Summary}

The West Indian assemblage of xenodontine snakes was found to be nonmonophyletic with respect to mainland xenodontines, despite difficulties in handling polymorphic allozyme data. Interestingly, the P/A results were more "intuitively reasonable" than the UP data set. The W. I. xenodontines appear to be divided into three or four groups, each with mainland relationships. These results suggest the need for nomenclatural changes to Alsophis, Arrhyton, Darlingtonia, and laltris to reflect evolutionary history. These results broadly agree with Dunn (1932) and Maglio (1970), but not with Jenner (1981) or Cadle (1985). In general, however, Cadle's (1984a,b, 1988) 
split of the xenodontines into South American and Central American groups is supported, as is also the phylogeny of Jenner and Dowling (1985), but only with the P/A result. The possible general agreement of the allozyme data with the previous hypotheses suggests that soon fundamental lines of relationships among the xenodontine radiation can be laid down, but such progress unquestionably will require the examination of additional data sets. The results also suggest that a review of morphological characteristics is in order for these snakes. And finally, these results provide additional data for detailed phylogenetic analyses of the West Indian and mainland groups, all of which may be useful in investigations into Caribbean-Central American historical biogeography.

\section{MATERIAL EXAMINED}

Voucher specimens are lodged in several different collections and some of these specimens are yet to be catalogued. Unless noted otherwise, the abbreviations denoting the collections follow Leviton et al. (1985). The six digit numbers are SBH field tags and are to be catalogued in the USNM. The zp field tag numbers are to be catalogued in the UCR collection. Other field tag numbers are: JEC = John Cadle, HCD = Herbert Dessauer, USC = Brian Crother.

Amastridium veliferum

Alsophis antillensis

Alsophis cantherigerus

Alsophis elegans

Alsophis portoricensis

Alsophis rijersmai

Alsophis vudii
COSTA RICA: Heredia: La Selva OTS field station (MVZ 206315)

RLB15P56a - 58a

CAYMAN BRAC ISLAND (JEC 7146); CUBA:

Guantanamo U. S. Naval Base; golf course nursery (TNHC 50099); waterfront building (TNHC 50100); Cuzco Beach (UMRC 86-1); Ocean View housing near Cable Beach (TNHC 50098)

PERU: Lima; Paraiso (JEC 7146)

PUERTO RICO: Guayama; 12 km N Guayama on Rte 179 (101831); San Juan; Urb. Beverly Hills (101830); Mayaguez; $1.5 \mathrm{~km}$ W Playa de Tamarindo (160062); Isla de Culebra (TNHC 50088)

ANGUILLA (MPM 23411)

BAHAMAS: Berry Islands (HCD 2755); Berry Islands; Frazer's Hog Cay (UMRC 86-37, 38, 39) 
Antillophis parvifrons

Arrhyton callilaemum

Arrhyton exiguum

Arrhyton funereum

Arrhyton landoi

Arrhyton polylepis

Arrhyton taeniatum

Coniophanes fissidens

Conophis lineatus

Crisantophis nevermanni

Darlingtonia haetiana

Enulius flavitorques

Farancia abacura

Geophis hoffmanni

Geophis zeledoni

Hypsirhynchus ferox

laltris dorsalis

Imantodes cenchoa
HAITI: I'Ouest; Croix des Bouquets (UMRC 86-26 [7 specimens], UMRC 86-27, UMRC 86-29 [2 specimens]); $1.6 \mathrm{~km}$ E Carrefour Marmelade (UMRC 86-30); lle de la Gonave; Etroits (UMRC 86-28 [4 specimens])

JAMAICA: St. Andrews Parish; Irish Town (USC 7540, 7597); Maryland Town (USC 7598-99)

PUERTO RICO: Poblado Castaner (TNHC 50089); Aquadilla; $23.5 \mathrm{~km}$ E Mayaguez at Parador Juanit on Rte 357 (161303); Cuchilla de Pandura, 1.9 km NE Vista Alegre on Rte 939 (160050)

JAMAICA: Westmoreland Parish; Woodstock (UMRC 8635); Bethel Town (USC 7499, UMRC 86-36, 7237-38)

CUBA: Guantanamo U.S. Naval Base $(161985,161893-$ 95)

JAMAICA: Portland Parish; Windsor Forest (USC 786970);

CUBA: Guantanamo U.S. Naval Base; Cuzco Beach (KU 269993)

COSTA RICA: (CRE 6818, 8885, 8917, 8975)

COSTA RICA: Puntarenas; Punto Morales (CRE 4689)

COSTA RICA: Guanacaste; Palo Verde (CRE 4692)

HAITI: Ouest; Furcy (UMRC 86-33); Grand'Anse; 2-3 km S Castillon (103806-811)

COSTA RICA: Guanacaste; La Pacifica (CRE 4729)

southern Florida (256F); Tamiami Trail $10 \mathrm{mi}$. W Krome Ave. (TNHC 50103)

COSTA RICA: Heredia: La Selva OTS field station (CRE 7425, MVZ 206318)

COSTA RICA: Alajuela; Cinchona (CRE 4731)

DOMINICAN REPUBLIC; Barahona; vicinity of Barahona (101393); HAITI (HCD 2733); lle de Gonave; Etroits (UMRC 86-34 [3 specimens])

HAITI: Grand'Anse; ca. 3 km N Bois Sec (103702)

COSTA RICA: Heredia; La Selva OTS field station (MVZ 206320-21, ZP 234, CRE 7354, CRE 10097, 6859, 8904) 
Imantodes inornatus

COSTA RICA: Heredia; La Selva OTS field station (Zp 43, CRE 6860, 6909)

Leptodeira septentrionalis COSTA RICA: Heredia; Pto. Viejo (CRE 4732, 4733, 4690); La Selva OTS field station (CRE 7311);

Puntarenas; $1 \mathrm{~km}$ NW of Rio Salema Nuevo on Hwy 2 (CRE 4720); CRE 6936, 8874, 8875, 8888, 8955)

Manolepis putnami

MEXICO: Guerrero; 15.2 mi. NW of Puerto Escondido on Hwy 200 (HCD 5303)

Nerodia fasciata

FLORIDA (TNHC 50106-50111); NW of Fakahatchee Strand (TNHC 50104); Florida City, Card Sound Rd. (TNHC 50105)

Ninia maculata

COSTA RICA: Alajuela; Cinchona (CRE 4730);

Ninia psephota

COSTA RICA: Heredia; La Selva OTS field station (zp 495)

Oxyrhopus petola

COSTA RICA: Heredia; Pto Viejo (CRE 4743); gift from Serpentario Cladimiro Picado (CRE 4723); (CRE 10099)

Rhadinaea calligaster COSTA RICA: Heredia; La Selva OTS field station (MVZ 206326-27, zp 556, CRE 7440)

Rhadinaea godmani

HONDURAS (USC 8072)

Saphenophis sneiderni

COLOMBIA (JMR 2459)

Sibon nebulata

COSTA RICA: Heredia; Pto. Viejo (CRE 4694, 8974)

Tretanorhinus nigroluteus

COSTA RICA (CRE 6939)

Uromacer catesbyi

HAITI: I'Ouest; Croix des Bouquets (UMRC 86-18 [8 specimens], UMRC 86-17 [11 specimens]); lle de Gonave; Etroits (UMRC 86-19 [2 specimens])

Uromacer frenatus

HAITI: I'Ouest; Croix des Bouquets (UMRC 86-22 [2 specimens], UMRC 86-21 [4 specimens], USC 7282, UMRC 86-23 [7 specimens], UMRC 86-24)

Uromacer oxyrhynchus

HAITI: I'Ouest; Croix des Bouquets (UMRC 86-15 [5 specimens], UMRC 86-16)

Xenodon rabdocephalus

COSTA RICA: gift from the Serpentario Clodomiro Picado (CRE 4722)

\section{ACKNOWLEDGEMENTS}


This paper resulted in part from my dissertation research which was completed at the University of Miami (FL). I am grateful to C. Mallery, J. C. Lee, D. M. Hillis, A. Schwartz, and J. M. Savage for their guidance, especially the late A. Schwartz and J. M. Savage. D. J. Morafka kindly provided the initial encouragement. M. M. Miyamoto, S. D. Werman, and H. Dessauer are thanked for their lessons in protein electrophoresis. Tissues were kindly donated by H. Dessauer, J. E. Cadle, R. Highton, S. B. Hedges, D. M. Hillis, L. D. Wilson, A. Schwartz, R. Henderson, J. Renjifo, J. B. Slowinski, M. P. Hayes and P. N. Lahanas. The following are thanked for enlightening, and sometimes heated, discussion: R. Calvo, M. A. Donnelly, C. Guyer, M. Grover, B. Grayson, J. M. Savage, S. D. Werman, J. B. Slowinski, M. Hayes, M. M. Miyamoto, P. N. Lahanas and D. McKey. D. M. Hillis, J. B. Slowinski, J. M. Savage, A. Schwartz and A. Williams contributed valuable help with fieldwork. Financial support for this project was provided by A. Schwartz, N. Witcher, the Department of Biology at the University of Miami (FL), the NOYES Foundation, and a grant from the National Geographic Society (364987). Logistic support while traveling was provided by J. E. Cadle, D. M. and A. Hillis, P. Harvey, P. Williams, J. Williams, A. Williams, D. Scales (Man-of-theYard), L. White, B. Rasmussen, W. Plankinger and C. Gonterman; I am extremely grateful for their help. The late Albert Schwartz, M. E. White, S. Werman, and D. Frost provided helpful comments. Preparation of the manuscript was partially funded by the National Science Foundation (DEB9207751).

\section{LITERATURE CITED}

BUTH, D. G.

1984a. The application of electrophoretic data in systematic studies. Annual Review of Ecology and Systematics 15: 501-522. 1984b. Allozymes of the cyprinid fishes: Variation and application. Pages 561- 590 in Evolutionary genetics of fishes, (B. J. Turner ed). Plenum Press, New York.

CADLE, J. E.

1984a. Molecular systematics of neotropical xenodontine snakes: I. South American xenodontines. Herpetologica 40: 8-20. 1984b. Molecular systematics of neotropical xenodontine snakes: II. Central American xenodontines. Herpetologica 40: 21-30. 1984c. Molecular systematics of neotropical xenodontine snakes: III. Overview of xenodontine phylogeny and the history of New World 
snakes. Copeia 1984: 641-652.

1985. The neotropical colubrid snake fauna (Serpentes: Colubridae): Lineage components and biogeography. Systematic Zoology 34: 1-20. 1987. The geographic distribution of snakes: Problems in phylogeny and zoogeography. Pages 77- 105 in Snakes: Ecology and evolutionary biology, (R. A. Seigel, J. T. Collins and S. S. Novak, eds). MacMillan Publishing Company, New York.

1988. Phylogenetic relationships among advanced snakes. A molecular perspective. University of California Publications in Zoology 119: 1-77.

AND H. W. GREENE.

1993. Phylogenetic patterns, biogeography, and the ecological structure of Neotropical snake assemblages. Pages 281-293 in Species diversity in ecological communities: Historical and geographical perspectives, (R. E. Ricklefs and D. Schluter, eds). University of Chicago Press, Chicago.

CAMPBELL, J. E. AND D. R. FROST.

1993. Anguid lizards of the genus Abronia: Revisionary notes, descriptions of four new species, a phylogenetic analysis, and key. Bulletin of the American Museum of Natural History 216: 1-121.

CANNATELLA, D. C. AND K. DE QUEIROZ. 1989. Phylogenetic systematics of the anoles: Is a new taxonomy warranted? Systematic Zoology 38: 57-69.

CARPENTER, J. M.

1992. Random cladistics. Cladistics 8: 147-153.

, J. E. STRASSMANN, S. TURILLAZZI, C. R. HUGHES, C. R. SOLIS AND R. CERVO.

1993. Phylogenetic relationships among paper wasp social parasites and their hosts (Hymenoptera: Vespidae: Polistinae). Cladistics 9: 129146.

CHAMPION, A. B., E. M. PRAGER, D. WACHTER AND A. C. WILSON. 1974. Microcomplement fixation. Pages 397-416 in Biochemical and Immunological Taxonomy of Animals, (C. A. Wright ed). Academic Press, London.

CROTHER, B. I. 
1990. Is "some better than none" or do allele frequencies contain phylogenetically useful information? Cladistics 6: 277-281.

AND D. M. HILLIS.

1995. Nuclear ribosomal DNA restriction sites, phylogenetic information, and the phylogeny of some xenodontine (Colubridae) snakes. Journal of Herpetology 29: 316-320.

, J. A. CAMPBELL AND D. M. HILLIS.

1992. Phylogeny and historical biogeography of the palm-pitvipers, genus Bothriechis: Biochemical and morphological evidence. Pages 119 in Biology of the pitvipers, (J. A. Campbell and E. D. Brodie, Jr., eds). Selva Press, Tyler.

AND C. GUYER.

1996. Caribbean historical biogeography: Was the dispersal-vicariance debate eliminated by an extraterrestrial bolide? Herpetologica 52: 440465.

DE QUEIROZ, A. AND R. LAWSON.

1994. Phylogenetic relationships of the garter snakes based on DNA sequence and allozyme variation. Biological Journal of the Linnean Society 53: 209-229.

AND W. E. DUELLMAN.

1978. Systematic herpetology: A synopsis of families in higher categories. Hiss Publications, New York.

R. HIGHTON, G. C. MAHA AND L. R. MAXON.

1983. Biochemical evaluation of colubrid snake phylogeny. Journal of Zoology London 201: 309-329.

, AND J. V. JENNER.

1988. Snakes of Burma. Checklist of reported species and bibliography. Smithsonian Herpetological Information Service 76: 1-19.

DOWNS, F. L.

1967. Intrageneric relationships among colubrid snakes of the genus Geophis Wagler. Miscellaneous Publications Museum of Zoology University of Michigan 131: 1-193. 


\section{DUNN, E. R.}

1925. Amastridium, a neglected genus of snakes. Proceedings of the United States National Museum. 65: 1-3.

1932. The colubrid snakes of the Greater Antilles. Copeia 1932: 89-92.

1939. Mainland forms of the snake genus Tretanorhinus. Copeia 4: 212217.

FAITH, D. P. AND P. S. CRANSTON.

1991. Could a cladogram this short have risen by chance alone? On permutation tests for cladistic structure. Cladistics 7: 1-28.

FARRIS, J. S.

1969. A successive approximations approach to character weighting. Systematic Zoology 18: 374-385.

1981. Distance data in phylogenetic analysis. Pages 3-23 in Advances in Cladistics Vol. 1, Proceedings of the Willi Hennig Society, (V. A. Funk and D. R. Brooks, eds). The New York Botanical Garden, Bronx, New York.

1985. Distance data revisited. Cladistics 1:67-85.

1989. The retention index and the rescaled consistency index. Cladistics 5: 417-419.

, M. KÄLLERSJÖ, A. G. KLUGE AND C. BULT.

1994. Permutations. Cladistics 10: 65-76.

FELSENSTEIN, J.

1978. The number of evolutionary trees. Systematic Zoology 27: 27- 33. 1985. Confidence limits on phylogenies: An approach using the bootstrap. Evolution 39: 783-791.

FUERST, P. A. AND R. E. FERREL.

1980. The stepwise mutation model: An experimental evaluation utilizing hemoglobin variants. Genetics 94: 185-201.

HEDGES, S. B. AND O. H. GARRIDO. 1992. Cuban snakes of the genus Arrhyton: Two new species and a reconsideration of $A$. redimitum. Herpetologica 48: 168-177.

HILLIS, D. M. 1987. Molecular versus morphological approaches to systematics. Annual Review of Ecology and Systematics 18: 23-42. 
1991. Discriminating between phylogenetic signal and random noise in DNA sequences. Pages 278-294 in Phylogenetic analysis of DNA sequences, (M. M. Miyamoto and J. Cracraft, eds). Oxford University Press, New York.

AND J. J. BULL.

1993. An empirical test of bootstrapping as a method for assessing confidence in phylogenetic analysis. Systematic Biology 42: 182-192.

AND J. P. HUELSENBECK.

1992. Signal, noise, and reliability in molecular phylogenetic analyses. Journal of Heredity 83: 189-195.

HOLMAN, J. A. 1984. Texasophis galbreathi, new species, the earliest New World colubrid snake. Journal of Vertebrate Paleontology 3: 223-225.

HORN, H. S.

1969. Polymorphism and the evolution of the Hispaniolan snake genus Uromacer (Colubridae). Breviora 324: 1-23.

HUELSENBECK, J. P

1991. Tree-length distribution skewness: An indicator of phylogenetic information. Systematic Zoology 40: 257-270.

JENNER, J. V.

1981. A zoogeographic study and the taxonomy of the xenodontine colubrid snakes. Unpublished Ph. D. Dissertation, New York University. 1983. Allocation of genera (Table X). Pages 309-329 in Biochemical evaluation of colubrid snake taxonomy $(\mathrm{H}$. G. Dowling, R. Highton, G. C. Maha, and L. R. Maxson, eds). Journal of Zoology, London 201.

AND H. G. DOWLING.

1985. Taxonomy of American xenodontine snakes: The tribe

Pseudoboini. Herpetologica 41: 161-172.

KÄLLERSJÖ, M., J. S. FARRIS, A. G. KLUGE AND C. BULT. 1992. Skewness and permutation. Cladistics 8: 275-287.

KLUGE, A. G. 
1991. Boine phylogeny and research cycles. Miscellaneous Publications Museum of Zoology, University of Michigan 178: 1-58.

AND A. J. WOLF.

1993. Cladistics: What's in a word? Cladistics 9: 183- 199.

AND J. S. FARRIS.

1969. Quantitative phyletics and the evolution of anurans. Systematic Zoology 18: 1-32.

LEVITON, A. E., R. H. GIBBS, JR., E. HEAL AND C. E. DAWSON. 1985. Standards in herpetology and ichthyology: Part I. Standard symbolic codes for institutional resource collections in herpetology and ichthyology. Copeia 1985: 802-832.

MABEE, P. M. AND J. HUMPHRIES.

1993. Coding polymorphic data: Examples from allozymes and ontogeny. Systematic Biology 42: 166-181.

MADDISON, W. P., M. J. DONOGHUE AND D. R. MADDISON. 1986. Outgroup analysis and parsimony. Systematic Zoology 33: 83103.

AND D. R. MADDISON.

1992. MacClade. Version 3.01. Computer program and manual. Sinauer Associates, Sunderland.

MAGLIO, V. J.

1970. West Indian xenodontine colubrid snakes: Their probable origin, phylogeny, and zoogeography. Bulletin of the Museum of Comparative Zoology 141: 1-54.

MAXSON, L. R. AND R. D. MAXSON.

1990. Proteins II: Immunological techniques. Pages 127-155 in Molecular systematics, (D. M. Hillis and C. Moritz, eds). Sinauer Associates, Sunderland.

MCDOWELL, S. B.

1987. Systematics. Pages 3-50 in Snakes: Ecology and evolutionary biology, (R. A. Seigel, J. T. Collins and S. S. Novak, eds). MacMillan Publishing Company, New York. 
MICKEVICH, M. F. AND M. JOHNSON.

1976. Congruence between morphological and allozyme data in evolutionary influence and character evolution. Systematic Zoology 25: 260-270.

AND C. MITTER.

1981. Treating polymorphic characters in systematics: A phylogenetic treatment of electrophoretic data. Pages 45-58 in Advances in Cladistics Vol. 1, Proceedings of the Willi Hennig Society, (V. A. Funk and D. R. Brooks, eds). The New York Botanical Garden, Bronx, New York.

MIYAMOTO, M. M.

1983. Frogs of the Eleutherodactylus rugulosus group: A cladistic study of allozyme, morphological, and karyological data. Systematic Zoology 32: 109-125.

MURPHY, R. W.

1988. The problematic phylogenetic analysis of interlocus heteropolymer isozyme characters: A case study from sea snakes and cobras. Canandian Journal of Zoology 66: 2628-2633.

1993. The phylogenetic analysis of allozyme data: Invalidity of coding alleles by presence/absence and recommended procedures.

Biochemical Systematics and Ecology 21: 25-38.

AND B. C. CRABTREE.

1985. Evolutionary aspects of isozyme patterns, number of loci, and tissue-specific gene expression in the prairie rattlesnake, Crotalus viridis viridis. Herpetologica 41: 451-470.

, I. S. DAREVSKY, R. D. MACCULLOCH, J. FU AND L. A.

KUPRIYANOVA.

1996. Evolution of the bisexual species of Caucasian rock lizards: A phylogenetic evaluation of allozyme data. Russian Journal of Herpetology 3: 18-31.

, J. W. SITES, JR., D. G. BUTH AND C. H. HAUFLER. 1990. Proteins I: Isozyme electrophoresis. Pages 45-126 in Molecular systematics, (D. M. Hillis and C. Moritz, eds). Sinauer Associates, Sunderland. 
MYERS, C. W.

1973. A new genus for Andean snakes related to Lygophis boursieri and a new species (Colubridae). American Museum Novitates 2522: 1-37. 1974. The systematics of Rhadinaea (Colubridae), a genus of New World snakes. Bulletin of the American Museum of Natural History 153: 1-262.

1982. Blunt-headed vine snakes (Imantodes) in Panama, including a new species and other revisionary notes. American Museum Novitates 2738: $1-50$.

\section{AND J. A. CAMPBELL.}

1981. A new genus and species of colubrid snake from the Sierra Madre del Sur of Guerrero, Mexico. American Museum Novitates 2708: 1-20.

NIXON, K. C. AND J. I. DAVIS.

1991. Polymorphic taxa, missing values and cladistic analysis. Cladistics 7: 233-241.

OHTA, T. AND M. KIMURA.

1973. A model of mutation appropriate to estimate the number of electrophoretically detectable alleles in a genetic population. Genetic Research 22: 201-204.

PINDELL, J. L. AND S. F. BARRETT. 1990. Geological evolution of the Caribbean region: A plate-tectonic perspective. Pages 405-432 in The geology of North America Vol. H, The Caribbean region, (G. Dengo and J. E. Case, eds). The Geological Society of America, Boulder.

PINOU, T. AND H. G. DOWLING. 1994. The phylogenetic relationships of the Central American snake Tretanorhinus: Data from morphology and karyology. AmphibiaReptilia 15: 297-305.

PLEIJEL, F. 1995. On character coding for phylogeny reconstruction. Cladistics 11 : 309-315.

RAGE, J. C. 
1987. Fossil history. Pages 51-76 in Snakes: Ecology and evolutionary biology, (R. A. Seigel, J. T. Collins and S. S. Novak, eds). MacMillan Publishing Company, New York.

ROSEN, D. E.

1975. A vicariance model of Caribbean biogeography. Systematic Zoology 27: 159-188.

SAVAGE, J. M.

1982. The enigma of the Central American herpetofauna: Dispersals or vicariance? Annals of the Missouri Botanical Garden 69: 464-547.

AND B. I. CROTHER.

1989. The status of Pliocercus and Urotheca (Serpentes: Colubridae), with a review of included species of coral snake mimics. Zoological Journal of the Linnean Society 95: 335-362.

AND P. N. LAHANAS.

1991. On the species of the colubrid snake genus Ninia in Costa Rica and western Panama. Herpetologica 47:37-53.

SCHWANER, T. D. AND H. C. DESSAUER. 1982. Comparative immunological survey of snake transferrins focused upon the relationships of the natricines. Copeia 1982: 541-549.

SCHWARTZ, A. AND O. H. GARRIDO. 1981. A review of the Cuban members of the genus Arrhyton (Reptilia, Serpentes, Colubridae). Annals of Carnegie Museum 50: 207-230.

SCOTT, N. J., JR. 1969. A zoogeographic analysis of the snakes of Costa Rica. Unpublished Ph. D. Dissertation, University of Southern California.

SITES, J. W., JR., R. L. BEZY AND P. THOMPSON. 1986. Nonrandom expression of lactate dehydrogenase isozymes in the lizard family Xantusiidae. Biochemical Systematics and Ecology 14: 539-545.

SOKAL, R. R. AND F. J. ROHLF. 1981. Taxonomic congruence in the Leptopodomorpha re-examined. Systematic Zoology 30: 309-325. 
SWOFFORD, D. L.

1993. PAUP: Phylogenetic analysis using parsimony, Version 3.1.1.

Illinois Natural History Survey, Champaign.

AND S. H. BERLOCHER.

1987. Inferring evolutionary trees from gene frequency data under the principle of maximum parsimony. Systematic Zoology 36: 293-325.

AND G. J. OLSEN.

1990. Phylogeny reconstruction. Pages 411-501 in Molecular

systematics, (D. M. Hillis and C. Moritz, eds). Sinauer Associates, Sunderland.

WATROUS, L. E. AND Q. D. WHEELER.

1981. The out-group method of character analysis. Systematic Zoology 30: $1-11$.

WELLMAN, J.

1963. A revision of snakes of the genus Conophis (Family Colubridae), from Middle America. University of Kansas Publications Museum of Natural History 15: 251-295.

WERMAN, S. D. 1997. Lactate dehydrogenase variation in neotropical pitvipers. Pages 79-88 in Venomous snakes: Ecology, evolution and snakebite, (R. S. Thorpe, W. Wuster and A. Malhotra eds). Clarendon Press, Oxford.

WILSON, L. D. AND J. R. MEYER.

1969. A review of the colubrid snake genus Amastridium. Bulletin of the Southern California Academy of Science 68: 146-160.

Submitted: Monday 23 November 1998 09:39:57 +1000 (EST) 